\title{
Możliwości komunikacyjne dziecka z zespołem Aspergera
}

ABSTRACT: Iwona Konieczna, Możliwości komunikacyjne dziecka z zespołem Aspergera [Communication possibilities of child with Asperger's syndrome]. Interdyscyplinarne Konteksty Pedagogiki Specjalnej, nr 11, Poznań 2015. Pp. 125-139. Adam Mickiewicz University Press. ISSN 2300-391X

Last time a huge progress of researches regarding communication possibilities of children with Asperger's syndrome can be noticed. Despite of this, the knowledge concerning this subject seems to be insufficient. There is also indisputable fact, that communication both on linguistic and non - linguistic level is incorrect. Disorders in this area might have different nature. Some children can be on a satisfactory level in linguistic area, some did not carve communication skills in sufficient level and it is hard to predict their development in this area. Additional difficult are huge differences between development of their communication skills. Communication ability is not only a part of socialization but also impacts on emotional and cognitive development, mainly because of it allows to extend area of experiences and understandding of world and people. Abnormalities which can be seen in development of children with Asperger's syndrome dispose to think what kind of methods can be used in order to make efficient their functioning in social area.

KEY WORDS: communication possibilities, communication qualifications, child with Asperger's syndrome

Relacja jednostki $\mathrm{z}$ otaczającym ją światem zewnętrznym, a zwłaszcza $\mathrm{z}$ innymi osobami, jest podstawą ukonstytuowania wielu współczesnych dyscyplin naukowych z obszaru nauk społec- 
znych. Obszarem, na gruncie którego dochodzi do spotkań między realnie istniejącymi osobami, jest sfera społeczna, w której nieuchronnie odbywają się podziały, wyznaczanie granic i kategoryzacji grupowych. „Inny” - w kategorii człowiek - może być postrzegany jako odmienny ze względu na określone, ujawniane przez niego cechy bądź przypisywane mu atrybuty. Tego rodzaju „inność" może być interpretowana $\mathrm{w}$ kategoriach obcości strukturalnej, która ujawnia się przez pryzmat doświadczeń związanych z wkroczeniem w obszar "innego" porządku społecznego, „innego" dyskursu kształtującego reguły, sposób funkcjonowania, świat społeczny, dostarczając innych wzorów działania, znaczeń i sposobów interpretacji tego, co się dzieje obok nas ${ }^{1}$.

W ostatnim czasie obserwuje się postęp prac badawczych nad językowymi możliwościami dzieci z zespołem Aspergera. Pomimo tego wiedza na temat komunikacji tej grupy osób wydaje się być ciągle niewystarczająca. Bezsporny jest także fakt, iż komunikacja zarówno na poziomie językowym, jak i niejęzykowym u tych osób nie jest prawidłowa. Zaburzenia $\mathrm{w}$ jej obrębie mogą mieć różny charakter. Jedne dzieci funkcjonują pod względem językowym na zadowalającym poziomie, inne nie opanowały umiejętności mówienia $\mathrm{w}$ wystarczającym stopniu, co więcej - trudno jest przewidzieć dalszy ich rozwój w tym obszarze. Dodatkową trudnością w rozwoju kompetencji komunikacyjnych jest to, że dzieci wykazują istotne różnice między sobą pod tym względem. Sprawność porozumiewania się jednostki nie jest tylko elementem jej socjalizacji, lecz także wpływa na rozwój poznawczy i emocjonalny dziecka; przede wszystkim dlatego, że umożliwia powiększanie obszaru doświadczeń oraz ułatwia rozumienie świata i ludzi. Nieprawidłowości, jakie daje się zauważyć w rozwoju komunikacji dzieci z zespołem Aspergera, skłaniają do tego, aby zastanowić się jakimi metodami możemy usprawnić ich funkcjonowanie w przestrzeni społecznej.

Osoby z zespołem Aspergera charakteryzują się brakiem empatii, pedantyczną repetatywną mową, ubogą komunikacją, głęboką

1 J. Rzeźnicka-Krupa, Inny i pedagogika: doświadczenie inności i relacja z innym jako istotne kategorie nauk o wychowaniu, "Studia Edukacyjne” nr 28/2013, s. 31-45. 
analizą określonych sytuacji, niezaradnością i zaburzoną motoryką. Jest ono percepowane jako zaburzenie ze spektrum autyzmu². Występujące różnice między autyzmem a zespołem Aspergera w odniesieniu do kryteriów diagnostycznych mają związek głownie z rozwojem językowym. Jego tempo w przypadku dziecka z zespołem Aspergera jest prawidłowe, w przypadku dzieci z autyzmem jest on opóźniony ${ }^{3}$.

W charakterystykach funkcjonowania dzieci/osób z zespołem Aspergera podkreślane jest zaburzenie komunikacji, którego skutkiem jest zagubienie w rzeczywistości społecznej. Zagubienie to ma dwa wymiary: jednostkowy (zagubienie się dziecka w przestrzeni społecznej na skutek zaburzonych i utrudnionych relacji społecznych) oraz społeczny (zagubienie osoby, której funkcjonowanie społeczne odbiega od przyjętych norm i reguł poprzez brak systemu wparcia). Bardzo często nawet osoby z najbliższego otoczenia dzieci z zespołem Aspergera nie rozumieją istoty zaburzenia, a przez to nie potrafią efektywnie wpierać ich w rozwoju. Zrozumienie istoty zaburzenia jest fundamentem nie tylko do właściwego zaspokajania potrzeb osoby z zespołem Aspergera, ale także do stworzenia warunków do wielostronnego funkcjonowania osoby w przestrzeni społecznej.

Międzynarodowa klasyfikacja WHO ICD-10 charakteryzuje zespół Aspergera następująco: „to zaburzenie o niepewnej wartości nozologicznej, charakteryzujące się tymi samymi nieprawidłowościami w zakresie interakcji społecznych jak autyzm oraz ograniczonym, stereotypowym repertuarem zainteresowań i aktywności"4.

U osób z zespołem Aspergera zaburzenia komunikacyjne określane są w wybranych kryteriach diagnostycznych:

2 T. Attwood, Zespót Aspergera, Wydawnictwo Zysk i S-ka, Poznań 1998; U. Frith, Autyzm i zespót Aspergera, Wydawnictwo Lekarskie PZWL, Warszawa 2005; U. Frith, Autyzm. Wyjaśnienie tajemnicy, GWP, Gdańsk 2008; E. Pisula, Autyzm u dzieci. Diagnostyka, klasyfikacja, etiologia, PWN, Warszawa 2001; E. Pisula, Od badan mózgu do praktyki psychologicznej. Autyzm, Wydawnictwo GWP, Sopot 2015.

${ }^{3}$ E. Pisula, Od badan mózgu do praktyki psychologicznej..., s. 17.

${ }^{4}$ www.icd10data.com/ICD10CM/Codes/F01-F99/F80-F89/F84-/F84.5 [15.03.2015]. 
(1) osobliwa mowa oraz zaburzenia komunikacji niewerbalnej;

(2) niezwykły sposób mówienia i cechy języka, czemu towarzyszy co najmniej jeden z następujących właściwości: (a) opóźniony rozwój mowy, (b) powierzchownie perfekcyjna ekspresja słowna, (c) sztywny, pedantyczny język, (d) dziwaczna prozodia, niezwykłe charakterystyki w operowaniu głosem, (e) ograniczona zdolność rozumienia języka łącznie z niewłaściwą interpretacją literalnych/figuratywnych znaczeń5;

(3) zaburzenia w komunikacji niewerbalnej - przynajmniej jedno z następujących: (a) ograniczona sugestia, (b) niezdarna lub niezręczna mowa ciała, (c) ograniczona mimika twarzy, (d) niewłaściwa ekspresja, (e) osobliwa chłodne spojrzenie ${ }^{6}$;

(4) samotnictwo - minimum dwa z poniższych: (a) brak bliskich przyjaciół, (b) unikanie innych ludzi, (c) brak zainteresowania zawieraniem przyjaźni, (d) samotnik;

(5) upośledzenie interakcji społecznych - co najmniej dwa z następujących: (a) zwracanie się do innych ludzi tylko wtedy, gdy chodzi o spełnienie potrzeb, (b) niezdarne kontakty społeczne, (c) jednostronne reakcje rówieśników, (d) trudności w wyczuwaniu emocji i uczuć innych ludzi, (e) brak reakcji na odczucia innych;

(6) zaburzenia komunikacji niewerbalnej - co najmniej jeden z następujących: (a) ograniczona ekspresja mimiczna, (b) brak możliwości odczytywania emocji z mimiki innych, (c) brak zdolności porozumiewania się spojrzeniami, (d) niepatrzenie na innych, (e) niewykorzystywanie gestów rąk jako środka ekspresji, gesty są „niezdarne”, (f) podchodzenie zbyt blisko do innych;

(7) dziwny sposób mówienia - co najmniej dwa z następujących: (a) nieprawidłowe stosowanie zasad związanych z fleksją,

${ }^{5}$ C.Ch. Gilberg, 1989, za: T. Attwood, Zespót Aspergera, Wydawnictwo Zysk i S-ka, Poznań 1998, s. 59.

${ }^{6}$ A. Kozdroń, Zespót Aspergera. Zrozumieć aby pomóc, Wydawnictwo Difin, Warszawa 2015, s. 17. 
(b) mówienie zbyt dużo, mówienie zbyt mało, (c) brak spójności w rozmowie, (d) idiosynkratyczne użycia słownictwa, (e) repetytywność - powtarzające się wzory mowy? .

Klasyfikacja DSM - V z 2013 r. wprowadziła istotne zmiany w zakresie zaburzeń autystycznych. Zostały one zaprezentowane w nowym ujęciu pod nową nazwą zaburzenia ze spektrum autyzmu (ASD), w skład których obecnie wchodzą: zaburzenia autystyczne, zespół Aspergera, dziecięce zaburzenia dezintegracji oraz całościowe zaburzenia rozwojowe gdzie indziej niediagnozowane ${ }^{8}$.

Badacze podkreślająa ${ }^{9}$ że komunikacja na poziomie językowym oraz niejęzykowym u osób z zespołem Aspergera nie przebiega prawidłowo lub jest zaburzona. Zmiany w jej obrębie mogą mieć różny charakter - od braku środków do komunikacji, po brak przyjmowania świadomej perspektywy rozmówcy. Deborah I. Garfin i Catherine Lord zwracają uwagę, że rozwój umiejętności porozumiewania się wymaga zaistnienia motywacji. W przypadku, kiedy dziecko nie odczuwa potrzeby nawiązywania interakcji z innymi, nasuwa się pytanie o sens działań, których celem jest praca nad rozwojem jego umiejętności komunikacyjnych. Proces kształtowania motywacji do porozumiewania się powinien być kluczowym elementem $\mathrm{w}$ zakresie rozwijania kompetencji komunikacyjnych $^{10}$.

Na podstawie analizy literatury przedmiotu można dojść do wniosku, iż niewiele jest badań odnoszących się do kompetencji komunikacyjnych osób z zespołem Aspegera. Zagraniczni badacze

7 P. Szatmari, J. Brenner i P. Nagyn, za: A. Kozdroń, op. cit., s. 18.

8 Warto wspomnieć, iż w 2015 roku klasyfikacja została opublikowana w języku polskim: P.S. Krawczyk Desk reference to the Diagnostic Criteria from DSM - 5, Wydawnictwo Edra Urban \& Partner Sp. z o.o., Wrocław 2015.

${ }^{9}$ U. Frith, Autyzm. Wyjaśnienie tajemnicy...; K. Markiewicz, Możliwości komunikacyjne dzieci autystycznych, Wydawnictwo UMCS, Lublin 2004; E. Pisula, Autyzm u dzieci....

10 D.I Garfin., C. Lord, Communication as a social problem in autism, [w:] Social Behavior in Autism, red. E. Schopler, G. Mesibov, Plenum Press, New York and London 1986 , s. $133-151$. 
podkreślają, że dzieci z zespołem Aspergera (50\%) wykazują opóźniony rozwój mowy, ale zazwyczaj w wieku 5 lat mówią płynnie ${ }^{11}$.

Opóźnienie rozwoju języka i zaburzone jego używanie w celach komunikacyjnych jest wskazywane wśród diagnostycznych kryteriów autyzmu w DSM i ICD - 1012. Żadne podejście naukowe czy preferowana metodologia nie podejmują próby wyjaśnienia tego, w jaki sposób język używany jest przez tę grupę osób w celach społecznych ${ }^{13}$. Badania używania języka przez osoby $\mathrm{z}$ zespołem Aspergera obejmują cztery sfery: składnię, semantykę, pragmatykę i fonetykę.

Nieliczne badania podkreślają problemy z wyrażaniem „znaczenia" w rozmowie ${ }^{14}$. Inne badania $\mathrm{z}$ kolei zwracały uwagę na problemy ze zrozumiem narracji i ogólnym panowaniem nad rozmową ${ }^{15}$.

U dzieci z zespołem Aspergera rozwój umiejętności fonetycznych i syntaktycznych odbywa się podobnie jak w przypadku dzie-

${ }^{11}$ R. Eisenymajer, M. Prior, S. Leekman, L. Wing, J. Gould, M. Welham, B. Ong, Comparison of clinical symptoms in autism and Asperger's Syndrome, "Journal of the American Academy of Child and Adolescent Psychiatry" 1996, 35, s. 1523-1531.

12 www.justines2010blog.files.wordpress.com/2011/03/dsm-iv.pdf [1.03.2015]. www.who.int/classifications/icd/ICD-10_2nd_ed_volume2.pdf [16.03.2015].

${ }^{13} \mathrm{~S}$. Dobbinson, M. R. Perkins, J. Baucher, Structural patterns in conversations with a woman who has autism, "Journal of Communication Disorders" 1998, 31, s. 113-134; C. Koning, J. Magill-Evans, Social and language skills in adolescent boys with Asperger syndrome, "Autism” 2001, 5, s. 23-36; R. Landa, J. Piven, M.M. Wzorek, J.O. Gayle, G.A. Chase, S.E. Folstein, Social language use in parents of autistic individuals, „Psychological Medicine” 1992, 22, s. 245-254; I. Martin, S. McDonald, An exploration of causes of non-literal language problems in individuals with Asperger syndrome, "Journal of Autism and Developmental Disorders" 2004, 34, s. 311-328.

${ }^{14}$ D.V.M. Bishop, J. Chan, C. Adams, J. Hartley, F. Weir, Conversational responsiveness in specific language impairment: Evidence of disproportionate pragmatic difficulties in a subset of children, ,JJournal of Development and Psychopathology" 2000, 12, s. 177-199.

${ }^{15}$ C. Adams, J. Green, A. Gilchrist, A. Cox, Conversational behavior of children with Asperger syndrome and conduct disorder, "Journal of Child Psychology and Psychiatry" 2002, 43, s. 679-690; D.V.M. Bishop, C.F. Norbury, Exploring the borderlands of autistic disorder and specific language impairment: a study using standardized diagnostic instruments, "Journal of Child Psychology and Psychiatry" 2002, 43, s. 917-929. 
ci w normie rozwojowej. Problem zaznacza się w obszarze semantyki ze względu na to, iż nie rozpoznają one różnych znaczeń tego samego słowa, a także w pragmatycznym użyciu języka oraz w prozodycznych elementach mowy takich jak intonacja, rytm wypowiedzi, akcent ${ }^{16}$.

Kolejnym problemem w zakresie możliwości komunikacyjnych dla dzieci z zespołem Aspergera jest brak zrozumienia zasad prowadzenia dialogu, szczególnie naprzemienności wypowiedzi. Bywa, że dzieci te nie potrafią słuchać swojego rozmówcy, rzadko decydują się na to, by być inicjatorem rozmowy, jeśli podejmują tę rolę, to odnosi się ona do ich specyficznych zainteresowań. Przyczyną tego może być duża wiedza dziecka w określonym obszarze, znajomość specjalistycznej terminologii, a co za tym idzie, poczucie bezpieczeństwa i swoboda wypowiedzi. W efekcie posługiwanie się określonym skryptem „uczestniczenia” w rozmowie powoduje, że dziecko z zespołem Aspergera ujawnia trudność w inicjacji, podtrzymaniu i zakończeniu prowadzonej rozmowy. Dodatkowym problemem dla niego jest nawiązanie kontaktu wzrokowego i utrzymanie go z rozmówcą. Zdarza się, że niektóre dzieci z zespołem Aspergera nie mówią zbyt wiele, inne z kolei nie pozwalają nikomu innemu na zabranie głosu. Bywa, że w trakcie rozmowy dzieci wtrącają wypowiedzi zupełnie niezwiązane z tematem, które mają charakter echolalii. Są one wynikiem jakościowych zaburzeń mowy i języka, które dziecko "skopiowało” z zupełnie innej rozmowy. Na uwagę zasługuje fakt, iż dzieci z zespołem Aspergera bardzo często są twórcami neologizmów ${ }^{17}$.

W literaturze poświęconej zagadnieniu komunikacji dzieci z zespołem Aspergera podkreśla się, iż często mają one problem ze zrozumieniem idiomów, żartów, sarkazmu, ukrytych lub wielorakich znaczeń; dosłownie interpretują usłyszane słowa, przerywają roz-

${ }^{16}$ J. Fine, G. Bartolucci, G. Ginsberg, P. Szatmari, The use of intonation to communicate in Pervasive Developmental Disorders, "Journal of Child Psychology and Psychiatry" 1991, 32, s. 111-112.

17 J. Volden, C. Loud, Neologism and idiosyncratic language in autistic speakers, „Journal of Autism and Developmental Disorders" 1991, 21, s. 109-130. 
mówcy i nie stosują się do przyjętych zasad konwersacji. Duży problem stanowi dla nich pojęcia kłamstwa, prawdy, zasadności komplementów i żartów ${ }^{18}$.

Bywa, że brakuje im odpowiednich słów, kiedy dopada ich stres, bezradność lub strach. Nie potrafią opisywać własnych emocji, strategią ujawnianą przez nie $w$ takich sytuacjach jest używanie wyrazów dźwiękonaśladowczych, wokalizowanie, śmiech, a nawet zdarza się, że zaczynają się jąkać ${ }^{19}$.

Wiele trudności pojawia się podczas analizy problemów ujawnianych przez dzieci z zespołem Aspergera w obszarze rozwoju językowego. Z uwagi na to, że jest to bardzo skomplikowany i długotrwały proces, należy rozwijać go jednocześnie pod kątem fonologicznym, morfologicznym, składniowym, leksykalnym, semantycznym i pragmatycznym. Cechą charakterystyczną tych kategorii jest to, że dzieci z zespołem Aspergera zaczynają używać pojedynczych słów przed ukończeniem 2. roku życia, zaś proste zdania budują przed 3. rokiem życia ${ }^{20}$.

Komunikacja językowa łączy ludzi ze względu na konieczność wymiany informacji. Umożliwia to język będący narzędziem, które służy do wyrażania wiedzy, myśli, emocji i opisywania otaczającej rzeczywistości. W przekazie informacji równie istotne są komunikaty niewerbalne (gesty, mimika), barwa, natężenie głosu, jak i stosunki przestrzenne między osobami prowadzącymi akt komunikacyjny ${ }^{21}$.

Rozwijanie kompetencji w tym obszarze jest związane $\mathrm{z}$ pragmatyczną wiedzą językową. W literaturze przedmiotu podkreśla się jej znaczenie w stosunku do kompetencji językowej. Badacze dowodzą, że niemowlę jest $\mathrm{w}$ stanie dzielić ze swoją matką pole wspólnej uwagi, stara się pojmować intencje innych, zaś w 9. miesiącu życia przekazuje je osobie tworzącej epizody wspólnej uwagi.

18 T. Attwood, op. cit., s. 68-69.

19 T. Jolliffe, R. Lansdown, C. Robinson, Autism: A personal account, "Communication Journal of the National Autistic Society" 1992, 26, s. 19.

${ }^{20}$ E. Pisula, Autyzm u dzieci....

${ }^{21}$ I. Kurcz, Psychologia języka i komunikacji, Wydawnictwo Naukowe Scholar, Warszawa 2000, s. 191. 
Narzędziem, które pozwala dziecku identyfikować i kreować pojęcia, jest język ${ }^{22}$. Według Michaela Tomasello23 podstawą poprawnego działania modułu językowego jest określony poziom dojrzałości umysłowej, pozwalający na zrozumienie i przyjęcie perspektywy innej jednostki. Według niego rozwój funkcji językowych powstaje w komunikacyjnego, a także intencjonalnego aspektu zachowań językowych. Aspekt ten uznawany jest za umiejętność przypisywaną tylko człowiekowi.

Analizując zachowania dzieci z zespołem Aspergera, można zauważyć, iż posiadają one umiejętność operowania językiem, jednak pozbawione jest to funkcji w odniesieniu do społecznych interakcji.

Badania Francesci Happe odnoszące się do analizy zależności między deficytami teorii umysłu a trudnościami komunikacyjnymi nakreślają założenia dotyczące teorii powiązań (ang. Relevance Theory). Teoria ta mówi o związkach pomiędzy sprawnością komunikacyjną a teorią umysłu. Wiedza, jaką dziecko zdobywa podczas społecznych interakcji komunikacyjnych, daje mu szansę na dokonywanie oceny intencji ludzi, z którymi wchodzi w relację. W konsekwencji pozwala określić zaburzenia komunikacyjne $\mathrm{w}$ rozwoju teorii umysłu, czyli postrzegania innych jednostek w kontekście określonej sytuacji24. Maria Kielar-Turska podaje, że język wpływa na rozwój teorii umysłu, natomiast rozwój reprezentacji umysłu wpływa zwrotnie na semantyczny i syntaktyczny rozwój języka ${ }^{25}$.

Dziecko z zespołem Aspergera stosuje charakterystyczny dla niego sposób przeformułowywania informacji. Odnosi się to do słabej centralnej koherencji, co oznacza umiejętność odczytywania informacji $\mathrm{w}$ określony sposób $\mathrm{w}$ danym kontekście bez koncen-

22 E. Pisula, Od badan mózgu do praktyki psychologicznej..., s. 37.

23 Tomasello M., The cultural origins of human cognition, Harvard University Press, Cambridge 1999, s. 134-160.

${ }^{24}$ F. Happe, Autism: An Introduction to Psychological Theory, University College London, London 1994, s. 76.

${ }_{25}$ M. Kielar-Turska, Badania nad dziecięcymi teoriami umystu i ich znaczenie dla klinicznej psychologii dziecka, [w:] Wspomaganie rozwoju, psychostymulacja i psychokorekcja, red. B. Kaja, Wydawnictwo Akademii Bydgoskiej, Bydgoszcz 2002, s. 92. 
trowania się na drobiazgach. Jest to związane $\mathrm{z}$ problemami $\mathrm{w}$ zakresie rozpoznawania sensu wyrazów w danym kontekście i brakiem umiejętności dekodowania informacji docierających z otoczenia w odniesieniu do ich dokładnego znaczenia.

Badania prowadzone przez Helen Tager-Flusberg ${ }^{26}$ pokazują pragmatyczną naturę problemów komunikacyjnych dzieci z zespołem Aspergera. Nieprawidłowości dotyczą gestykulacji, możliwości wypowiedzi, tempa mowy, rytmu, akcentowania, natężenia siły głosu adekwatnie do sytuacji. Dodatkowo dzieci z zespołem Aspergera nie są inicjatorami rozmowy oraz rzadko zabierają głos. $\mathrm{Na}$ uwagę zasługuje fakt, iż same dokonują wyboru tematu rozmowy, najczęściej temat ten dotyczy obszaru ich zainteresowań i za wszelką cenę chcą go kontynuować. Cechą charakterystyczną jest występowanie stereotypii językowych, odwracanie zaimków osobowych oraz echolalie. W przypadku dzieci z zespołem Aspergera echolalie są „magazynem” służącym do gromadzenia elementów słuchowych docierających z otoczenia. Echolalia może mieć charakter bezpośredni (powtórzenie natychmiast po usłyszeniu dźwięku, słowa), pośredni i odroczony (uruchamiana po pewnym czasie)27.

Bywa, że dzieci z zespołem Aspergera mają zaburzony słuch fonematyczny, co w konsekwencji wpływa na trudności w rozumieniu mowy. Występujące zaburzenia sensoryczne skutkują podwyższoną lub obniżoną wrażliwością na określone bodźce zmysłowe np. światło, temperaturę, zapach, dotyk, dźwięk. Zdarza się, że dużym problemem dziecka jest ujawniana nadwrażliwość słuchowa, co w efekcie utrudnia odbiór mowy, szczególnie kiedy jest więcej niż jeden rozmówca i do dziecka docierają inne dźwięki z otoczenia.

W literaturze przedmiotu jako główny problem dzieci z zespołem Aspergera wskazuje się zaburzenia komunikacji w obszarze językowym i pozajęzykowym. Używany przez nie język może być

${ }^{26} \mathrm{H}$. Tager-Flusberg, On the nature of linguistic functioning in early infantile autism, "Journal of autism and developmental disorders" 1981, 11, s. 45-46.

${ }^{27}$ H. Jaklewicz, Zaburzenia mowy w autyzmie wczesnodziecięcym, „Postępy Psychiatrii i Neurologii" 1994, 3, s. 375-381. 
zbyt pedantyczny, nadmiernie dojrzały, niedostosowany do poziomu rozwoju dziecka i jego wieku.

Badania przeprowadzone przez Paula Broca ${ }^{28}$ odnoszące się do zmian w mózgu u osób z afazją przyczyniły się do większego zainteresowania zaburzeniami mowy i ich zależności od dokonywanych zmian $w$ danych obszarach mózgu. $W$ trakcie komunikowania się istotną rolę odgrywa prawa półkula mózgu. Występujące w niej zmiany są przyczyną zaburzonej komunikacji niewerbalnej, która podobnie jak komunikacja werbalna odgrywa dużą rolę $\mathrm{w}$ interakcjach społecznych, tak jak i elementy prozodii, z którymi osoby z zespołem Aspergera mają trudności. Dotyczą one przede wszystkim brzmienia głosu, intonacji oraz ich synchronizacji z gestem, mimiką czy przyjmowaniem odpowiedniej postawy ciała. Jak wiadomo, prawa półkula mózgu jest odpowiedzialna za orientację przestrzenną i identyfikację określonych przedmiotów, co jest niezwykle ważne $\mathrm{w}$ zakresie możliwości interpretacji ruchów ciała i mimiki twarzy podczas aktu komunikacji. $W$ prawej półkuli powstają motywy wzrokowe i słuchowe, które przyczyniają się do rozumienia otaczającej rzeczywistości. Z półkulą tą ma też związek inteligencja i szybkość reakcji na określony bodziec. Kenneth A. Bonnet i Xiao-Ke Gao ${ }^{29}$ opisują charakterystyczne cechy zespołu Aspergera, ujmując je jako te, które wpływają na osłabienie komunikacji społecznej i nieprawidłowości w zakresie komunikacji niewerbalnej. Przy czym należy dodać, że występujące nieprawidłowości u tej grupy osób nie wynikają z ujawnianych zachowań stereotypowych i umiejętności werbalnych. W konsekwencji może mieć to związek z nieprawidłowym funkcjonowaniu prawej półkuli mózgu. Zatem autorzy ci nie zauważają związku pomiędzy komunikacją werbalną a zaburzeniami w obrębie komunikacji niewerbalnej. Pomimo to $w$ dalszym ciągu badacze nie znaleźli jednoznacznej odpowiedzi na pytania dotyczące tego, na ile nieprawidłowe funk-

28 J.P. Mohr, Broca's area and Broca's aphasia, [w:] Studies in neurolingustics, red. H. Whitaker, Academic, New York 1976, s. 201-236.

${ }^{29}$ K.A. Bonnet i X.K. Gao, Asperger syndrome in neurologic perspective, "Journal of child neurology" 1996, 11(6), s. 483-489. 
cjonowanie określonych struktur mózgowych wpływających na pracę funkcji językowych ma związek $\mathrm{z}$ przetwarzaniem semantycznym u dzieci z zespołem Aspergera.

\section{Zakończenie}

Oczywisty wydaje się fakt, że osoby z zespołem Aspergera ujawniają zaburzenia komunikacyjne na różnych poziomach, co $\mathrm{w}$ konsekwencji wpływa na ich sposób porozumiewania się $\mathrm{z}$ innymi. Dzieci z zespołem Aspergera prezentują zróżnicowany repertuar reakcji i zachowań komunikacyjnych. Ze względu na ograniczenia $\mathrm{i}$ zaburzenia $\mathrm{w}$ komunikowaniu się, często mają one trudności w nawiązywaniu interakcji i relacji społecznych. Należy podkreślić, że ze względu na interakcyjny charakter procesu komunikowania także osoby będące $\mathrm{z}$ nimi $\mathrm{w}$ relacjach napotykają wiele trudności. Dotyczy to zarówno rozpoznawania znaczących komunikatów, jak i interpretowania reakcji i zachowań komunikacyjnych. Trudności w komunikowaniu dzieci z zespołem Aspergera (oraz $\mathrm{z}$ nimi) powodują ich problemy $\mathrm{w}$ funkcjonowaniu społecznym, a przecież każdy człowiek, niezależnie od jego osobistej sytuacji, poziomu funkcjonowania czy też doświadczeń ma prawo do uczestnictwa w życiu społecznym.

U dzieci z zespołem Aspergera problemy z rozumieniem i ekspresją mogą przybierać bardzo różną postać i natężenie: od całkowitego braku rozumienia określonych sytuacji komunikacyjnych/ /społecznych po subtelne pomyłki w ich interpretacji; od braku potrzeby komunikacji po zaburzenia zdolności inicjowania i podtrzymywania rozmowy z innymi mimo dobrego opanowania mowy i języka.

Zatem wspieranie rozwoju dziecka z zespołem Aspergera bezwzględnie musi obejmować rozwój kompetencji komunikacyjnych. Aby proces wspierania był efektywny, powinien mieć charakter systemowy. $\mathrm{W}$ zawiązku z różnorodnością cech komunikacji ujętych $\mathrm{w}$ różnych kryteriach diagnostycznych oraz klasyfikacjach 
zasadne wydaje się opracowanie modelu, w którym nie tylko zostanie zdefiniowane pojęcie kompetencje komunikacyjne dzieci z zespołem Aspergera, ale także wskazane zostaną sposoby ich funkcjonalnej oceny oraz zasady wspierania rozwoju kompetencji komunikacyjnych. Można sądzić, iż w praktyce zarówno terapeuci, opiekunowie, rodzice, jak i inne osoby wspierające rozwój dziecka z zespołem Aspergera będą mogli na tej podstawie określić prawidłowości w rozwijaniu jego komunikacji. Efektywne komunikowanie się zwłaszcza w otoczeniu społecznym wspomaga wielka liczba ukrytych zasad i niuansów. Dlatego też opracowanie modelu kompetencji komunikacyjnych uczniów z zespołem Aspergera jest niezbędnym warunkiem wspierania porozumiewania się jednostki w różnych relacjach społecznych. Może to wpisywać się w model diagnozy dla jakości życia dzieci z zespołem Aspergera, jak też wskazywać na możliwość rozpoznawania kompetencji komunikacyjnych w różnych sytuacjach społecznych, ale obecnie wydaje się to być zadaniem na przyszłość.

\section{Bibliografia}

Adams C., Green J., Gilchrist A., Cox A., Conversational behavior of children with Asperger syndrome and conduct disorder, "Journal of Child Psychology and Psychiatry" 2002, 43.

Attwood T., Zespót Aspergera, Wydawnictwo Zysk i S-ka, Poznań 1998.

Bonnet K.A., Gao X.K., Asperger syndrome in neurologic perspective, "Journal of child neurology", 1996, 11(6).

Bishop D.V.M., Chan J., Adams C., Hartley J., Weir F., Conversational responsiveness in specific language impairment: Evidence of disproportionate pragmatic difficulties in a subset of children, "Journal of Development and Psychopathology" 2000, 12.

Bishop D.V.M., Norbury C.F., Exploring the borderlands of autistic disorder and specific language impairment: a study using standardized diagnostic instruments, „Journal of Child Psychology and Psychiatry" 2002, 43.

Cytowska B., Wilczura B., Wczesna interwencja i wspomaganie rozwoju matego dziecka, Oficyna Wydawnicza „Impuls”, Kraków 2006.

Dobbinson S., Perkins M.R. Baucher J., Structural patterns in conversations with a woman who has autism, "Journal of Communication Disorders" 1998, 31. 
Eisenymajer R., Prior M, Leekman S., Wing L, Gould J, Welham M, Ong B., Comparison of clinical symptoms in autism and Asperger's Syndrome, "Journal of the American Academy of Child and Adolescent Psychiatry" 1996, 35.

Fine J., Bartolucci G., Ginsberg G., Szatmari P., The use of intonation to communicate in Pervasive Developmental Disorders, "Journal of Child Psychology and Psychiatry" 1991, 32.

Frith U., Autyzm i zespót Aspergera, Wydawnictwo Lekarskie PZWL, Warszawa 2005.

Frith U., Autyzm. Wyjaśnienie tajemnicy, GWP, Gdańsk 2008.

Garfin D.I., Lord C., Communication as a social problem in autism [w:] Social Behavior in Autism, Plenum Press, red. E. Schopler, Mesibov G., New York and London 1986.

Gillberg C., Gillberg I.C, Asperger syndrome - some epidemiological considerations: a research note, "Journal of Child Psychology and Psychiatry" 1989, 30.

Happe F., Autism: An Introduction to Psychological Theory, University College London, London 1994.

Jaklewicz H., Zaburzenia mowy w autyzmie wczesnodziecięcym, „Postępy Psychiatrii i Neurologii" 1994, 3.

Jolliffe T., Lansdown R., Robinson C., Autism: A personal account, "Communication Journal of the National Autistic Society" 1992, 26.

Kielar-Turska M., Badania nad dziecięcymi teoriami umystu i ich znaczenie dla klinicznej psychologii dziecka, [w:] Wspomaganie rozwoju, psychostymulacja i psychokorekcja, red. B. Kaja, Wydawnictwo Akademii Bydgoskiej, Bydgoszcz 2002.

Koning C., Magill-Evans J., Social and language skills in adolescent boys with Asperger syndrome, "Autism” 2001, 5.

Kozdroń A., Zespót Aspergera. Zrozumieć aby pomóc, Wydawnictwo Difin, Warszawa 2015.

Krawczyk P.S., Desk reference to the Diagnostic Criteria from DSM - 5, Wydawnictwo Edra Urban \& Partner Sp.z o.o., Wrocław 2015.

Kurcz I., Psychologia jezzyka i komunikacji, Wydawnictwo Naukowe Scholar, Warszawa 2000.

Landa R., Piven J., Wzorek M.M, Gayle J.O, Chase G.A., Folstein S.E. Social language use in parents of autistic individuals, „Psychological Medicine” 1992, 22.

Marcinkowska B., Model kompetencji komunikacyjnych osób z głębszą niepetnosprawnością intelektualna - w poszukiwaniu wzajemności i wspótpracy, Wydawnictwo APS, Warszawa 2013.

Markiewicz K., Możlizwości komunikacyjne dzieci autystycznych, Wydawnictwo UMCS, Lublin 2004.

Martin I., McDonald S., An exploration of causes of non-literal language problems in individuals with Asperger syndrome, "Journal of Autism and Developmental Disorders" 2004, 34.

Mohr J.P., Broca's area and Broca's aphasia, [w:] Studies in neurolingustics, red. H. Whitaker, Academic, New York 1976. 
Pisula E., Autyzm u dzieci. Diagnostyka, klasyfikacja, etiologia, PWN, Warszawa 2001.

Pisula E., Od badan mózgu do praktyki psychologicznej. Autyzm, Wydawnictwo GWP, Sopot 2015.

Rzeźnicka-Krupa J., Inny i pedagogika: doświadczenie inności i relacja z innym jako istotne kategorie nauk o wychowaniu, "Studia Edukacyjne” nr 28/2013.

Stech K., Kompetencje zawodowe nauczyciela - spojrzenie na problem, [w:] Kompetencje nauczyciela - wychowawcy, red. K. Ferenz, E. Koziol, Redakcja Wydawnictw Humanistyczno-Społecznych UZ, Zielona Góra 2002.

Tager-Flusberg H., On the nature of linguistic functioning in early infantile autism, "Journal of autism and developmental disorders" 1981, 11.

Tomasello M., The cultural origins of human cognition, Harvard University Press, Cambridge 1999.

Volden J., Loud C., Neologism and idiosyncratic language in autistic speakers, "Journal of Autism and Developmental Disorders" 1991, 21.

Williams D., Nikt nigdzie, Wydawnictwo Fraszka Edukacyjna we współpracy z Fundacją Synapsis, Warszawa 2005. 